\title{
Molecular Plant-Plum Pox Virus Interactions
}

\author{
Bernardo Rodamilans, ${ }^{\dagger}$ Adrián Valli, ${ }^{\dagger}$ and Juan Antonio García ${ }^{\dagger}$ \\ Departamento de Genética Molecular de Plantas, Centro Nacional de Biotecnología (CNB-CSIC), Campus Universidad \\ Autónoma de Madrid, 28049 Madrid, Spain
}

Accepted 23 August 2019.

\begin{abstract}
Plum pox virus, the agent that causes sharka disease, is among the most important plant viral pathogens, affecting Prunus trees across the globe. The fabric of interactions that the virus is able to establish with the plant regulates its life cycle, including RNA uncoating, translation, replication, virion assembly, and movement. In addition, plant-virus interactions are strongly conditioned by host specificities, which determine infection outcomes, including resistance. This review attempts to summarize the latest knowledge regarding Plum pox virushost interactions, giving a comprehensive overview of their relevance for viral infection and plant survival, including the latest advances in genetic engineering of resistant species.
\end{abstract}

Keywords: sharka disease, virus-plant interactions

Plum pox virus (PPV) is the causative agent of sharka, one of the most important diseases of trees of the genus Prunus. Thanks to its high propagation potential, PPV has spread worldwide, causing great damage to many economically important crops. PPV is a member of the genus Potyvirus in the family Potyviridae. This genus is one of the largest groups of plant viruses and includes 175 species recognized in the ICTV taxonomy release MSL\#34. Due to their abundance and the high economic relevance of some members, potyviruses are being the subject of intensive research. This is reflected in the nearly 8,000 articles published since the beginning of this century that were retrieved with the words "potyvirus" or "potyviridae" from the Web of Science databases as of July 2019. The impact of sharka disease in agriculture and the fact that the virus belongs to the relevant potyvirus group have placed PPV among the ten most important viruses in molecular plant pathology (Scholthof et al. 2011). Web of Science databases gathered more than 1,300 published scientific articles about PPV over the course of this century, including several recent comprehensive reviews (Barba et al. 2011; Cambra and Vidal 2017; Cirilli et al. 2016; Clemente-Moreno et al. 2015; García et al. 2014; Ilardi and Tavazza 2015; James et al. 2013; Rimbaud et al. 2015; Sochor et al. 2012). This review aims at updating the available information about i) the molecular features that define the PPV diversification in a fairly large number

${ }^{\dagger}$ Corresponding authors: B. Rodamilans; brodamilans@cnb.csic.es, A. Valli; avalli@cnb.csic.es, and J. A. García; jagarcia@cnb.csic.es

Funding: Work in the authors' laboratory was funded by grants from the Ministerio de Ciencia, Innovación y Universidades (AEI-FEDER) BIO201680572-R and BIO2015-73900-JIN.

The author(s) declare no conflict of interest.

C 2020 The American Phytopathological Society of different strains and ii) the virus-host interactions promoting either virus amplification or antiviral defense, causing disease symptoms, and contributing to host specificity, with the further inclusion of molecular approaches aiming to engineer protection against PPV. Although much of the data obtained for other potyviruses might be likely applied to PPV, we will mainly focus on results obtained directly for PPV, which may or may not be shared by other potyviruses.

\section{WHAT DETERMINES PPV DIVERSITY AND HOST SPECIFICITY?}

The PPV genome consists of a single-stranded RNA of positive polarity. Its primary translation product is processed by two leader proteases, P1 and HCpro, which cleave at their carboxyl ends, and the protease NIapro, which cuts the central and carboxyl region of the polyprotein and yields the mature viral factors P3, 6K1, CI, 6K2, VPg, NIapro itself, NIb, and coat protein (CP) (Fig. 1A) (García et al. 2014). An additional protein, P3N-PIPO, is translated from an RNA molecule with an extra A introduced by slippage of the viral RNA polymerase in a GA6 motif inside the P3 coding sequence (Rodamilans et al. 2015). PPV is a virus with high intraspecies diversity. Two PPV strains, Dideron (PPV-D) and Marcus (PPV-M), were distinguished as early as 1979 (Kerlan and Dunez 1979) and up to ten PPV strains are currently recognized, Cherry Volga (PPV-CV) being the last one established (Chirkov et al. 2018a; Hajizadeh et al. 2019) (Fig. 1B). In spite of frequent intra- and interstrain recombination events (Chirkov et al. 2018b; Hajizadeh et al. 2019; James et al. 2016), genome sequences soundly support PPV strains as molecularly distinct entities; however, the host range and biological properties of PPV are only partially strain-specific (Kamenova et al. 2017; Sihelská et al. 2017; Šubr et al. 2015). PPV-Cherry (PPV-C), PPV-Cherry Russian (PPV$\mathrm{CR}$ ), and PPV-CV are restricted to cherry in natural conditions, but they are able to infect other hosts experimentally. Among the most prevalent strains, PPV-M is mainly associated with peach, whereas PPV-D and PPV-Rec are associated with plum infections; however, isolates of the three strains have been found infecting plum, peach, apricots, and other Prunus hosts in the field (Sihelská et al. 2017). This promiscuity, along with the time-consuming experiments with woody plants and the uncertainty of extrapolating results obtained in the laboratory to infections that occur in nature, have hampered getting solid experimental data about molecular factors contributing to the preferential adaptation of PPV to different Prunus hosts.

Nonetheless, information is available concerning PPV and herbaceous species (Fig. 1A). Experiments with chimeric viruses made from different PPV isolates have demonstrated that optimal adaptation to several potential hosts can be mutually exclusive (Calvo et al. 2014b; Carbonell et al. 2013; 
Salvador et al. 2008a). These experiments, together with the analysis of viral progenies derived from trials of forced evolution revealed that determinants of host specificity are spread throughout the whole viral genome. Sequences relevant for PPV adaptation to particular hosts have been identified in P1 (Salvador et al. 2008a; Vozárová et al. 2013), the P3/P3N-PIPO + 6K1 region (Dallot et al. 2001; Salvador et al. 2008a; Vozárová et al. 2013), VPg (Calvo et al. 2014a), NIb (Wallis et al. 2007), and CP (Carbonell et al. 2013). In addition, experiments using chimeric viruses, this time between PPV and the ipomovirus cucumber vein yellowing virus (CVYV), another member of the family Potyviridae, evidenced the influence of the RNA-silencing suppressor HCpro in host specificity (Carbonell et al. 2012). Remarkably, this is in agreement with older results showing that HCpro defects contributed to restriction of systemic spread in the local PPV host Nicotiana tabacum (Sáenz et al. 2002).

The P1 protein has been shown to be especially relevant for host adaptation of potyviruses (Cui and Wang 2019; Valli et al. 2007), and several results exemplify this importance for PPV. Thus, the exchange of the P1 sequence in PPV by that of another potyvirus, tobacco vein mottling virus, abolished infectivity in Prunus persica but enhanced the infection efficiency in Nicotiana clevelandii (Salvador et al. 2008b). Another evidence of the relevance of P1 for host specificity comes from the observation that point changes in the P1 sequence of virus variants that coexist in a single PPV population conditioned viral accumulation and symptom severity in different ways, depending on the infected host (Maliogka et al. 2012 b). It has long been known that P1 is an expendable gene product but its self-cleavage activity is essential for viral infectivity (Verchot and Carrington 1995). More recently, it has been shown that the N-terminal part of PPV P1 is not only dispensable for the proteolytic activity of the protein but also has an inhibitory effect that must be counteracted by a yetunidentified host factor. Hence, it has been suggested that host-dependent regulation of $\mathrm{P} 1$ processing modulates potyviral replication and contributes to host specificity (Pasin et al. 2014). In line with this idea, the elimination of the N-terminal antagonist domain of the PPV P1 protease led to a gain-of-function phenotype, strongly enhancing its local infection in Cucumis sativus, a nonpermissive host for PPV (Shan et al. 2018). The replacement in PPV of its P1 by P1a of CVYV also supports the relevance of P1 self-cleavage for host specificity, as P1a facilitates the local replication of the PPV chimera in C. sativus, a natural host of CVYV, but impairs the infection in Nicotiana benthamiana, due to suboptimal self-processing (Shan et al. 2015).

It is expected that, similarly to the case of P1 self-release, the rest of proteolytic events of the viral polyprotein will involve host cofactors and will be subject to modulation in order to yield the different cleavage products at the appropriate amounts along the infection (Mann and Sanfaçon 2019; Rodamilans et al. 2018). In this scenario, the precise compatibility of viral and host partners involved in the proteolytic processing would likely contribute to the host-range definition. In agreement with this idea, single amino acid changes in the proximity of the 6K1-CI junction promoted the alternative adaptation of PPV-C isolates to cherry and $N$. benthamiana (Calvo et al. 2014b). This suggests that adaptation of PPV-C to these hosts relies on specific host factors, which contribute to a fine regulation of the proteolytic cleavage that separates $6 \mathrm{~K} 1$ from $\mathrm{CI}$.

\section{HOW IS PPV AMPLIFIED AND SPREAD?}

In spite of the extensive available information about the potyviral life cycle obtained in recent years, our knowledge
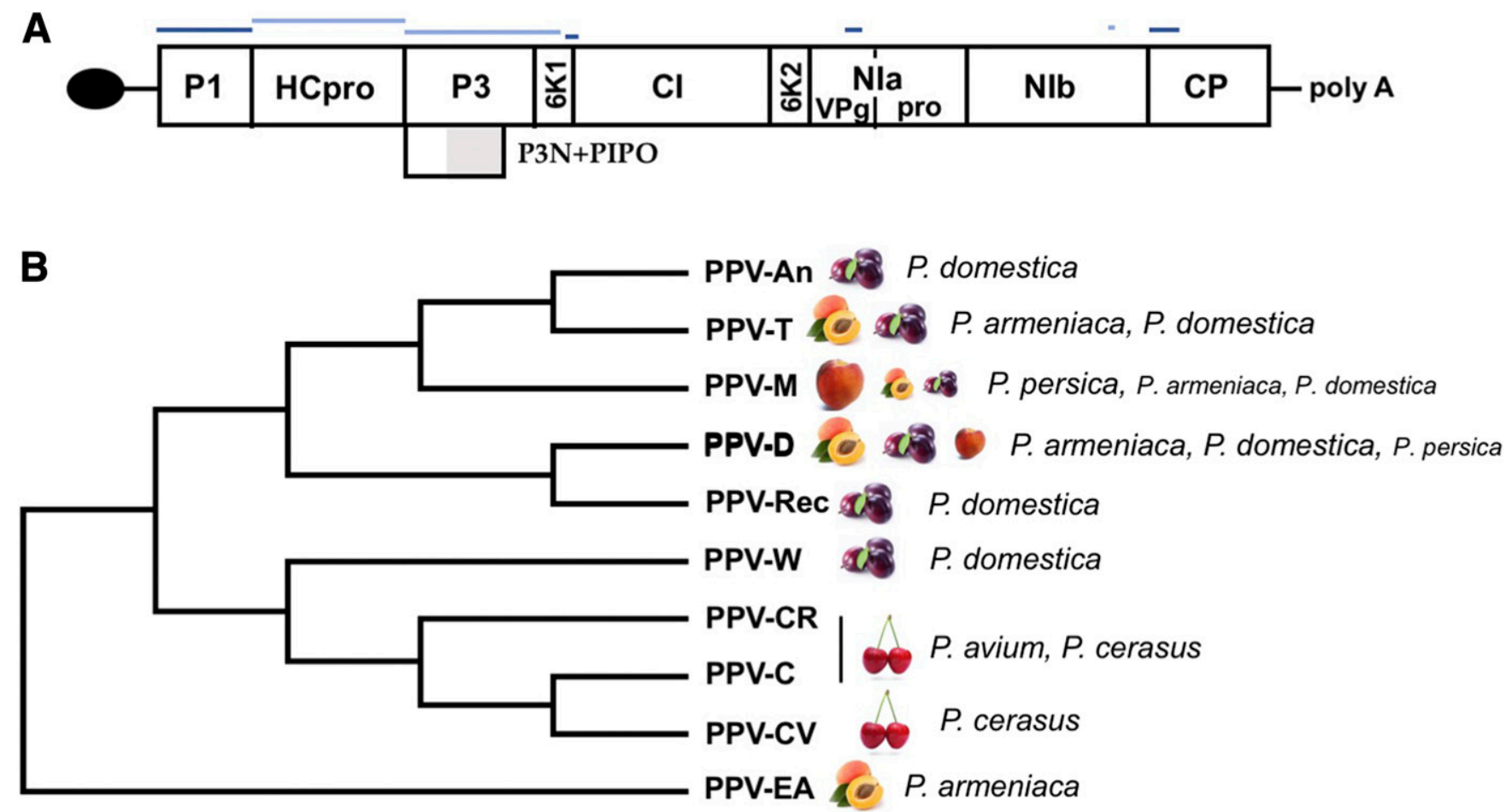

Fig. 1. A, Genomic map of plum pox virus (PPV). The encoded polyproteins are represented by boxes, with lines separating the indicated protein products. The PIPO open reading frame, translated from an RNA polymerase slippage product, is indicated by a gray box. Blue lines pinpoint sequences whose contribution to adaptation to new hosts has been demonstrated by strong (dark blue) or moderate (light blue) evidence. B, A phylogenetic tree and host ranges of PPV strains in nature. The definition of PPV-An as a bona fide strain is controversial (Hajizadeh et al. 2019). The tree was constructed with the MEGA program, applying the maximum likelihood method to full-length nucleotide sequences aligned by Muscle. The Prunus species more frequently infected by each strain are indicated at the end of the tree branches; the size of the names of the hosts and of their representative pictures correlates with their prevalence. 
about different steps of the infection as a whole can be compared with that of blind people examining an elephant, i.e., the different parts of the elephant are correctly described but the picture of the entire animal is still hazy. In this section, we discuss data obtained with PPV, with the aim of improving the quality of the general picture (Fig. 2).

The first step of the PPV infection inside the cell is the viral genome uncoating, but no specific information about it is available. Data from other potyviruses suggest that uncoating can be linked to viral movement and translation initiation, involving a protruding tip localized to one end of the virion, likely the one corresponding to the 5' end of the genomic RNA, which contains VPg, HCpro, and CI (Gabrenaite-Verkhovskaya et al. 2008; Torrance et al. 2006). This is consistent with the earlier detection of HCpro associated with PPV virions (Manoussopoulos et al. 2000). After the uncoating or, more likely, coupled to it, the genomic RNA is translated to produce the viral polyprotein. It is still unknown whether the translated RNA retains VPg attached to its $5^{\prime}$ end or if this protein is removed before translation, as occurs in the case of polioviruses (Ambros et al. 1978). What it is known for the RNA of PPV (Simón-Buela et al. 1997a) and other potyviruses (Miras et al. 2017) is that its translation is independent of cap. Two structured domains in the $5^{\prime}$ untranslated region (UTR) of the potyvirus tobacco etch virus (TEV) RNA were proposed to regulate cap-independent translation and facilitate internal translation initiation (Zeenko and Gallie 2005). However, reinterpretation of available evidence supports the relevance of conventional ribosome scanning for efficient translation of potyviral RNA (Miras et al. 2017). This is the mechanism that has been suggested for the translation initiation of PPV RNA (Simón-Buela et al. 1997a), in which the existence of specific sequences or structural elements necessary for the internal entry of ribosomes is unlikely, since sequences of the $5^{\prime}$ UTR essential for PPV infection are confined to the first 39 nucleotides (Simón-Buela et al. 1997b). Remarkably, PPV differs from most potyviruses in that its long open reading frame (ORF) starts at an AUG placed very close to the $5^{\prime}$ end of the genomic RNA. However, this ORF is translated from the second AUG, which is in a more favorable context for translation initiation (Riechmann et al. 1991). The fact that translation efficiently started at the first AUG when the neighboring sequence was conveniently modified supports the hypothesis that translation initiation of PPV RNA takes place by a leaky scanning mechanism (Simón-Buela et al. 1997a). Upstream AUGs have been shown to have significant impact in regulating the translation of the main ORFs (van der Horst et al. 2019). The proximal AUG is not essential for PPV infection in herbaceous hosts under laboratory conditions (Riechmann et al. 1991), but its extreme conservation in all PPV strains suggests that it could be important for PPV infection of Prunus hosts in nature.

Numerous works have studied the potyviral RNA replication and the potyvirus movement, which appears to be closely linked processes. Briefly explained, the $6 \mathrm{~K} 2$ protein induces a rearrangement of the endoplasmic reticulum (ER) and the

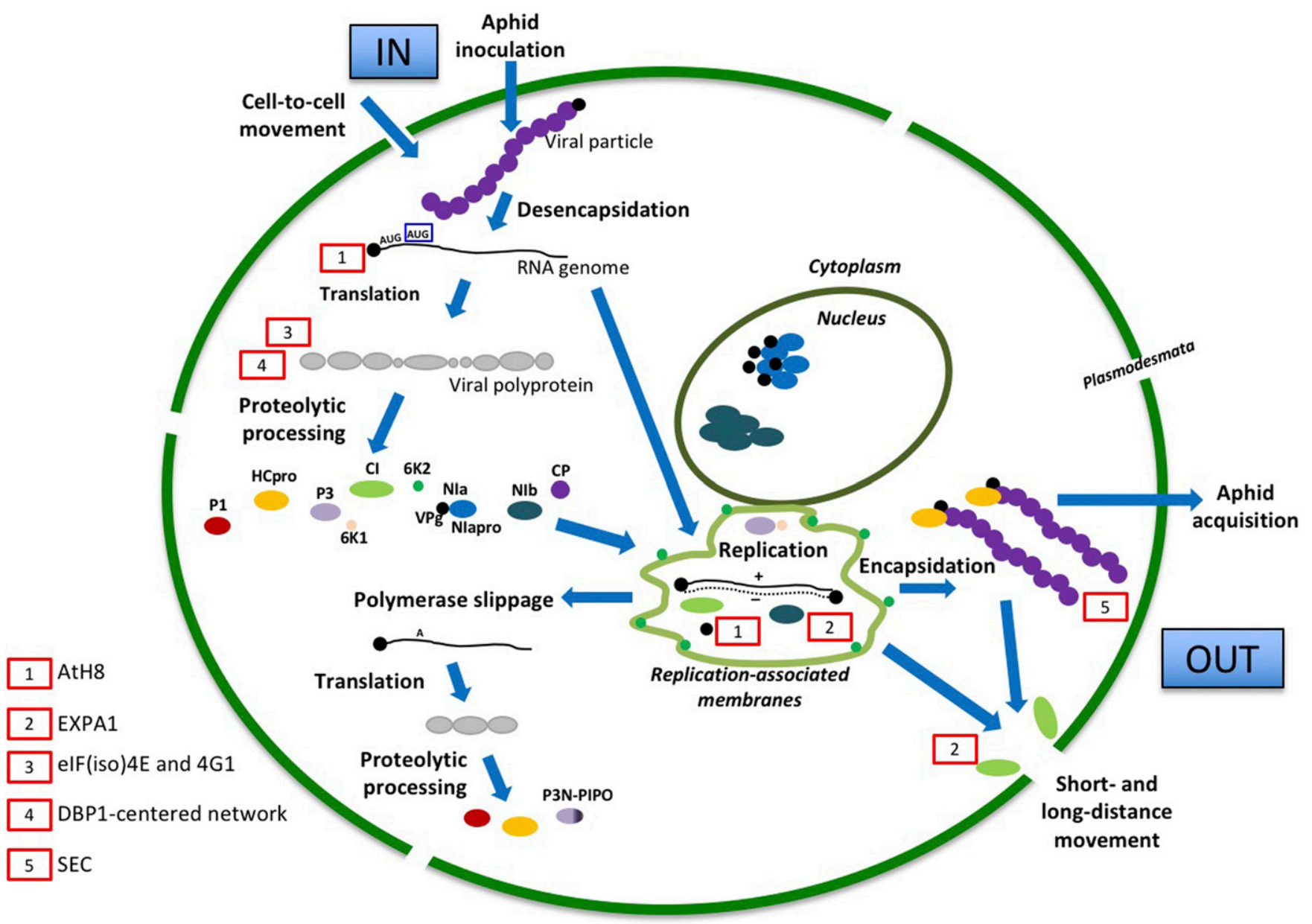

Fig. 2. Schematic representation of the most relevant events occurring when plum pox virus (PPV) enters a plant cell. Each viral protein is represented by different color-coded circumferences. Host factors specifically identified for PPV infection are indicated by number-coding red squares and are depicted in tentative locations where they play a role. 
formation of membrane vesicles, in which primary replication complexes are assembled (Schaad et al. 1997; Wei and Wang 2008). These vesicles traffic to the chloroplasts and are fused to their membranes (Garcia Cabanillas et al. 2018; Wei et al. 2013). Later, chloroplast-associated replication complexes aggregate in large perinuclear globular structures (Grangeon et al. 2012). In addition to $6 \mathrm{~K} 2$, most of the potyviral proteins have been found associated to replication vesicles and are thought to participate in viral RNA replication (Lõhmus et al. 2016), a process in which many host factors are involved (Garcia-Ruiz 2019; Nagy and Pogany 2012; Nagy et al. 2011; Wang 2015). Replication vesicles are also able to traffic intracellularly and through the plasmodesmata invading neighbor cells and spreading the infection to distant tissues (Jiang et al. 2015; Movahed et al. 2017; Wan et al. 2015). Viral proteins, mainly CI and P3N-PIPO, as well as host factors such as AtPCaP1 and SYTA, are involved in the modification of plasmodesmata necessary for viral movement (Movahed et al. 2017; Uchiyama et al. 2014; Vijayapalani et al. 2012; Wei et al. 2010).

There is not much information available regarding replication and movement of PPV. Early work showed the involvement of membrane fractions enriched in ER and tonoplast vesicles in PPV RNA synthesis (Martin et al. 1995). Shortly after the discovery of the RNA helicase activity of the PPV CI protein, it was demonstrated that this activity is required for PPV RNA replication (Fernández et al. 1997). The involvement of CI in virus movement has also been demonstrated for PPV, and the roles of the protein in movement and replication have been genetically dissected (Gómez de Cedrón et al. 2006). Apparently, CI is not the only RNA helicase involved in PPV infection, since the host DEAD-box RNA helicase-like protein AtRH8, which is able to interact with the VPg protein, was shown to be necessary for infection (Huang et al. 2010). The fact that AtRH8 colocalizes with chloroplastbound virus accumulation vesicles suggests that this putative RNA helicase could be involved in genome translation and replication. Another host factor involved in PPV infection is EXPA1, an $\alpha$-expansin that was identified in a proteomic study on a plasmodesmata-enriched fraction from $N$. benthamiana leaves in response to turnip mosaic virus (TuMV) infection. EXPA1 was recruited to the viral replication complexes, probably through its interaction with the RNA replicase $\mathrm{NIb}$, and was shown to promote genome replication and to facilitate the viral cell-to-cell movement of TuMV and PPV (Park et al. 2017).

Whereas the role of $6 \mathrm{~K} 2$ as inducer of the membrane remodeling needed for potyviral RNA replication has been thoroughly studied, the function of the first small peptide $6 \mathrm{~K} 1$ is less well-known. Results with PPV indicate that separation of $6 \mathrm{~K} 1$ from P3 is important but not essential for viral infection (Cui and Wang 2016; Riechmann et al. 1995), which is in agreement with the detection of $6 \mathrm{~K} 1$ as a free protein in PPVinfected plants (Waltermann and Maiss 2006). 6K1, which is able to interact in vivo with $\mathrm{CI}, 6 \mathrm{~K} 2$, and NIapro (Zilian and Maiss 2011), colocalizes in the early stages of infection with $6 \mathrm{~K} 2$-induced vesicles bound to chloroplasts, and mutations in a predicted hydrophobic helix domain and in other short conserved motifs were shown to abolish PPV infection (Cui and Wang 2016). Based on these results, it has been suggested that $6 \mathrm{~K} 1$ is a membrane protein that together with two other viral membrane proteins, $6 \mathrm{~K} 2$ and $\mathrm{P} 3$, facilitates the assembly of replication complexes in membrane vesicles at the beginning of the infection and that P3-6K1 can partially replace the function of free P3 and 6K1 proteins (Cui and Wang 2016).

Translation initiation factors are well-recognized susceptibility factors for potyviral infection but their precise role in the process is poorly understood (Ala-Poikela et al. 2011; Robaglia and Caranta 2006). Indeed, PPV infection depends on particular isoforms of translation initiation factors $4 \mathrm{E}$ and $4 \mathrm{G}$ [eIF(iso) $4 \mathrm{E}$ and eIF(iso)4G1, for Arabidopsis thaliana infection] (Nicaise et al. 2007). Although the way in which these factors contribute to PPV infection remains unknown, some host factors that might be involved in the eIF(iso)4E contribution have been identified. DBP1, a DNA-binding protein phosphatase, facilitates PPV infection by protecting eIF(iso)4E from degradation via proteasome (Castelló et al. 2010), while DIP2, a small DBP1-interactor, counteracts this protective effect (Castelló et al. 2011). The involvement of two extra DBP1 interactors, the protein kinase MPK11 and its substrate GRF6, in response to PPV infection adds complexity to the protein network centered on DBP1, whose role as a signaling component in PPVhost interaction is still far from being elucidated (Carrasco et al. 2014).

The last intracellular step of the potyviral infection is virion assembly, a process that is also rather unknown. Whereas the involvement of assembled virions, with the assistance of HCpro, in aphid transmission between plants is commonly accepted (Blanc et al. 1997), its participation in short- and longdistance movement is more debatable (Dolja et al. 1994; Wan et al. 2015). Although potyviral CP can form helical virion-like particles in both live and in vitro heterologous systems, accurate assembly of virus particles depend on the participation of other viral and probably also host factors. In particular, an activity of HCpro independent of its functions in aphid transmission and suppression of RNA silencing stabilizes CP and enhances the yield of infectious virus particles (Valli et al. 2014). It was hypothesized that this activity of HCpro could be involved in sorting the RNA devoted to being translated, replicated, or encapsidated. Of note, whereas heterologous viral silencing suppressors can functionally replace the equivalent activity of PPV HCpro (Carbonell et al. 2012; Maliogka et al. 2012a), only the HCpro from PPV is able to stabilize its cognate virions (Valli et al. 2014). Moreover, RNA replication is essential for the assembly of stable virus particles, highlighting the importance of coupling encapsidation to other viral processes (Gallo et al. 2018).

Dynamic posttranslational modifications (PTMs) can confer to proteins additional regulatory properties (Jakubiec and Jupin 2007). Two PTMs have been found to affect the CP of PPV, i.e., $O$-GlcNAcylation and phosphorylation (Chen et al. 2005; Fernández-Fernández et al. 2002; Šubr et al. 2007). Neither of the two modifications is essential for virus viability but both are important to achieve efficient viral infection (Martínez-Turiño et al. 2018; Pérez et al. 2013). The joint action of $O$-GlcNAcylation and phosphorylation might allow a fine tuning of $\mathrm{CP}$ and virion stability, providing the amounts of $\mathrm{CP}$ and naked RNA required in each step of the viral infection (MartínezTuriño et al. 2018). It is important to remark that $O$-GlcNAcylation and phosphorylation of $\mathrm{CP}$ appear to be almost PPV-exclusive. Only phosphorylation of potato virus A CP has been described (Lõhmus et al. 2017) but, apparently, with roles in the infection quite different from those of PPV CP (MartínezTuriño et al. 2018). Thus, it is possible that PTMs could provide a virus-specific extra layer of regulation for PPV infection.

\section{HOW DOES PPV CAUSE DISEASE?}

Metagenomics analyses have revealed that the majority of natural viral infections in plants do not cause noticeable symptoms (Roossinck 2012). Ironically, the most studied plant viruses are precisely the ones that cause damaging diseases with strong symptomatology (Pallas and García 2011; Wu et al. 2019). In many cases, these symptoms are the result of plant defensive responses rather than the consequence of specific 
actions of the virus against the host (Harris et al. 2013). In PPV, this is well-illustrated by the virus variant that lacks the antagonist domain of the P1 protein (discussed above), which causes more severe symptoms in Nicotiana species than those of the wild-type virus, as a consequence of the induction of a strong defensive response in which salicylic acid (SA) is involved (Pasin et al. 2014).

Disease symptoms of plant viral infections have also been found associated with disorders caused by the viral RNAsilencing suppressor in physiological processes regulated by micro (mi)RNAs (Chapman et al. 2004). Indeed, the RNAsilencing suppressor HCpro has been shown to condition the pathogenicity of PPV in herbaceous and woody hosts (González-Jara et al. 2005; Sáenz et al. 2001). Interestingly, in virus variants segregated from a natural PPV isolate, the severe symptoms associated with a particular HCpro sequence were attenuated, in a host-specific way, by single amino acid changes in the P1 protein (Maliogka et al. 2012b). The possibility exists that these amino acid changes are affecting the self-cleavage activity of P1 and that the pathogenicity is governed in the segregated virus variants by both the strength of the RNAsilencing suppression activity of HCpro and the efficiency of its release from $\mathrm{P} 1$.

Considerable effort has been devoted to understand the cytological and physiological alterations as well as the changes in gene expression, proteomic profiles, and biochemical activities associated with the induction of disease symptoms, both in experimental herbaceous plants and in natural Prunus hosts (Clemente-Moreno et al. 2015). The variety of experimental approaches and methodologies employed prevents, for the moment, assembling the multiple results in a fully comprehensive picture. However, what is well-established from different works is that PPV induces the accumulation of reactive oxygen species (ROS). The excess of ROS that cannot be rectified by plant antioxidant systems disorganizes the chloroplast structure and reduces the photosynthetic efficiency, provoking the development of disease symptoms (Fig. 3) (Clemente-Moreno et al. 2013; Diaz-Vivancos et al. 2006, 2008; Hernández et al. 2006). The oxidative stress appears to be a consequence of the pathogen-associated molecular patterntriggered antiviral immunity (PTI) launched by the plant, and the PPV CP seems to be involved in its suppression (Nicaise and Candresse 2017). In agreement with these assumptions, transcriptomic analyses at early times of infection detected changes in gene expression associated mainly with defense responses (Rubio et al. 2015a and b). Moreover, proteomic study showed that stress-responsive and photosynthesis-related proteins were more severely affected by the infection of an aggressive PPV isolate than by that of a mild isolate (Nováková et al. 2018).

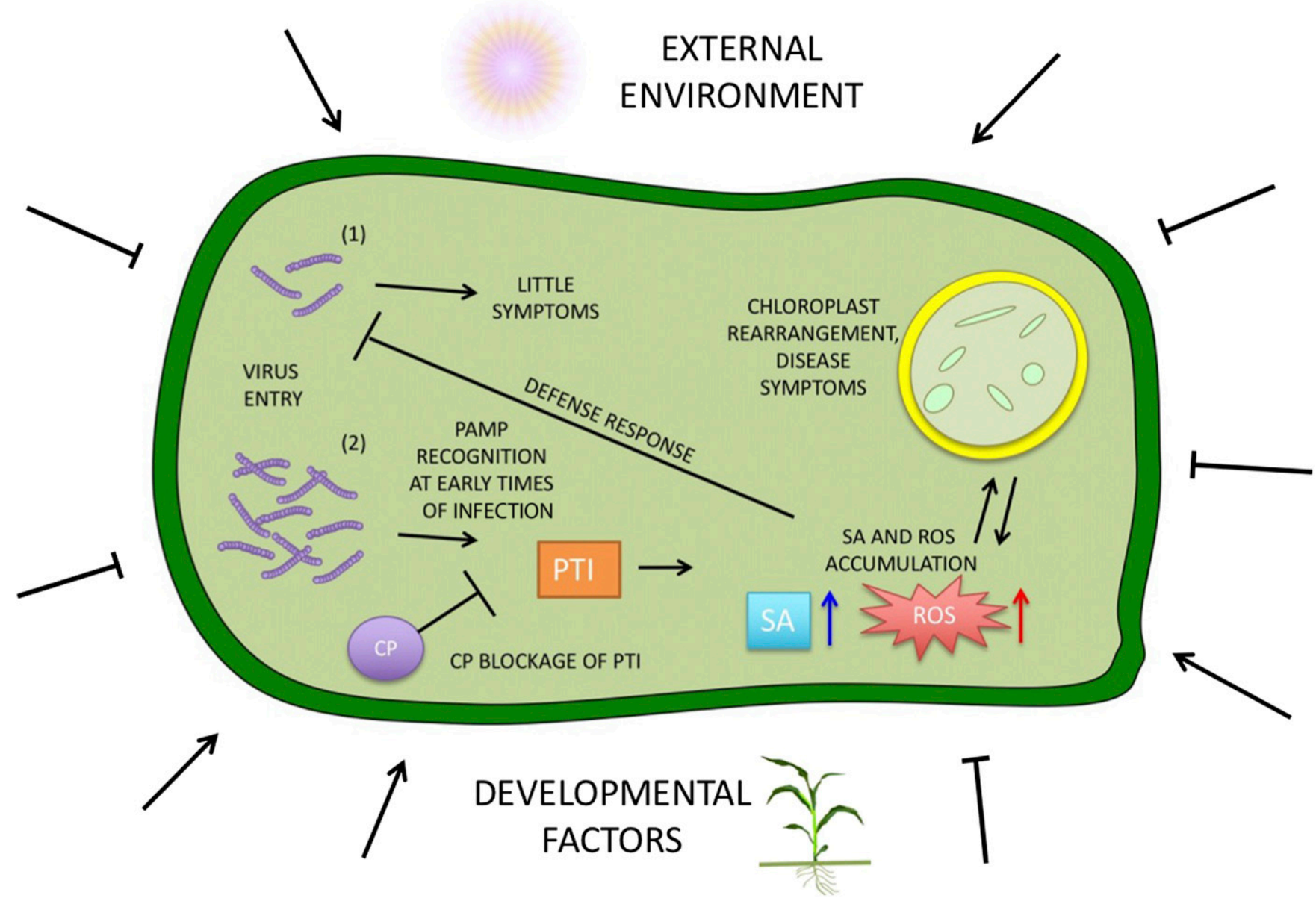

Fig. 3. Simplistic scenario of symptom development at the subcellular level after plum pox virus (PPV) infection. With low viral accumulation (1), response of the plant is mild and few symptoms are shown. When a high viral dosage is reached (2), there is viral recognition by pathogen-associated molecular patterns activating a pattern-triggered immunity (PTI) response, which is counteracted by the action of coat protein (CP). PTI causes an increase in salicylic acid (SA) and reactive oxygen species (ROS) that act as a defense barrier of the plant, while the increased oxidative stress activates chloroplast rearrangement and symptom development. Disruption of chloroplast function and photosynthesis by the virus triggers ROS production as well, providing feedback to the system. Symptoms are also dependent on external elements and may vary seasonally and according to plant developmental factors. 
PPV infection causes a drastic disturbance of the plant hormonal balance, which is expected to be determinant for the development of symptoms. SA appears to be linked to the necrotic symptoms associated to the defensive response elicited in Nicotiana species by the above-mentioned PPV mutant with unrestricted P1 self-cleavage activity (Pasin et al. 2014). Overaccumulation of SA has also been found associated with defensive responses in PPV infection of Prunus trees; however, in these cases the increase in SA levels is not accompanied by induction of disease symptoms. In fact, PPV-infected peach trees with severe disease symptoms had SA levels much lower than the control plants, and grafting of the infected peach tree with an almond scion, which caused a drastic drop in viral accumulation and disappearance of the symptoms (discussed below), greatly enhanced SA levels (Dehkordi et al. 2018). Similarly, treatment of peach seedlings with mandelonitrile (MD), a precursor of SA, provides partial protection against PPV infection and attenuates PPV-induced symptoms, and this effect correlates with increased SA levels (Diaz-Vivancos et al. 2017). Of note, the observed downregulation in PPV-infected peaches of polypeptides showing similarity to MD lyase, an enzyme involved in a metabolic pathway generating SA from $\mathrm{MD}$, could be a counter-defense activity of the virus to confront SA-mediated antiviral defense (Diaz-Vivancos et al. 2006).
SA is not the only hormone involved in PPV infection. In the article by Dehkordi et al. (2018) cited above, the authors observed profound changes in the phytohormone profiles of peach trees provoked by PPV infection and by the induction of an anti-PPV state due to grafting with an almond cultivar. Although results are still not very conclusive, imbalances in the levels of abscisic acid and gibberellin GA3 might be involved in the establishment of chlorotic symptoms.

\section{HOW DO PLANTS DEFEND THEMSELVES (OR CAN BE PROTECTED) FROM PPV?}

In general terms, plants can achieve pathogen resistance in an active dominant way, like the RNA silencing-mediated defense induced by viral double-stranded (ds)RNA and the gene-forgene resistance associated with resistance $(R)$ genes and the hypersensitive response (HR), or in a passive recessive way, often linked to plant-pathogen incompatibilities (Fig. 4A). The second type seems to be more common for viruses, especially for potyviruses, than for other plant pathogens (Truniger and Aranda 2009).

RNA silencing provides the main general defense mechanism against plant viruses. Dicer-like (DCL) dsRNAses, RNAdependent RNA polymerases (RDR), and argonaute (AGO)

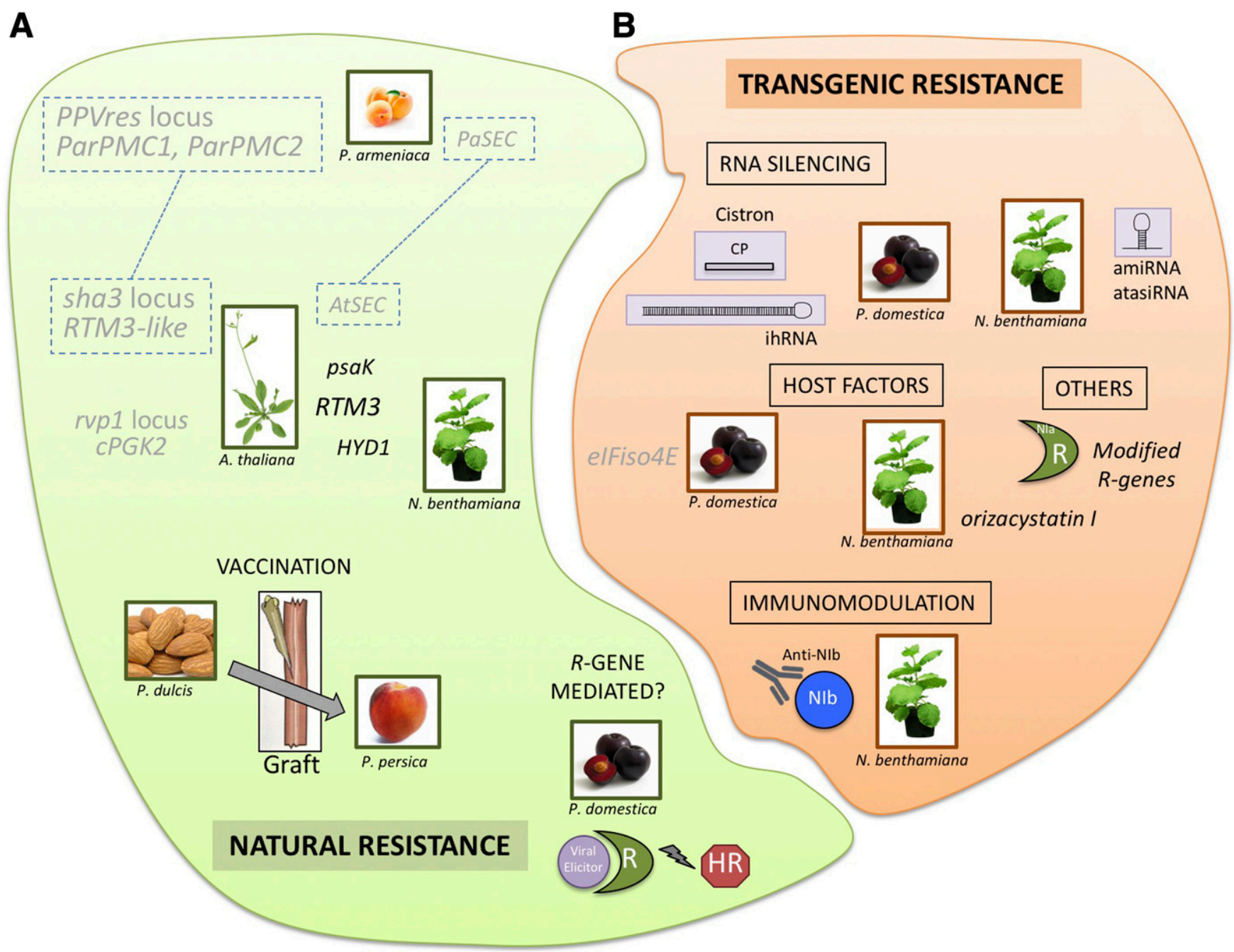

Fig. 4. Different resistance factors found in nature and engineered in genetically modified plants. A, Natural resistance. Plants carrying the specified factor, locus, or gene are shown. Factors that need to be present for resistance are in black; factors that need to be absent for resistance are in gray. Homologous genes are squared and linked with dotted lines. B, Transgenic resistance. Specific modifications are shown next to each plant. The eIFiso4E gene, which was silenced to induce resistance, is shown in gray. The rest of the factors introduced in the plants are shown in black. 
proteins are important components of the RNA-silencing machinery. The gene encoding one of these proteins, DCL2a, was shown to be overexpressed in peach and apricot trees infected with PPV (Rubio et al. 2015a and b). A more recent report detected three DCL2 gene homologs, six RDRl homologs, RDR6, AGO4, and AGO5 upregulated in leaves of plum leaves that are developing after cold-induced dormancy (Collum et al. 2020). Similar to other defense genes, they were preferentially activated in phloem tissue, which could provide a mobile defensive barrier at the front of the infection.

HR-related resistance against PPV has been described in the case of Prunus domestica. In the past 20 years, a solid breeding program has been developed that uses the variety Jojo as the genetic source of this resistance (Neumüller et al. 2010). There is, however, no information regarding the specific genes involved in it. RNAseq analysis provided some data regarding differentially expressed genes during HR in Jojo trees (Rodamilans et al. 2014), but no further characterization of the identified candidates has been performed.

Much more information is available regarding a specific kind of resistance, nonrelated to the $R$ gene pathways, found in apricots (Prunus armeniaca). Genetic linkage mapping followed by analyses of quantitative trait loci (QTL) identified several genomic regions involved in PPV resistance (Hurtado et al. 2002; Lambert et al. 2007). The locus that accounts for most of the phenotypic variances was termed PPVres, which was further validated by full genome sequencing and genomewide association studies (GWAS) (Mariette et al. 2016; Zuriaga et al. 2013). PPVres contains six genes encoding meprin and TRAF-C homology domain (MATHd)-containing proteins. These genes, related to viral movement (Decroocq et al. 2006), were selected as the most likely candidates for PPV resistance in apricot and were suggested as ideal tools for marker-assisted selection strategies (Zuriaga et al. 2013). A later study, however, showed that mutations in genes of the PPVres locus, including all MATHd-identified genes, were not enough to confer resistance to PPV (Decroocq et al. 2014). A more recent transcriptomic analysis (Zuriaga et al. 2018) comparing susceptible and resistant trees in response to PPV infection reinforced the original idea that the previously identified genes from the PPVres locus could be responsible for the resistance. This analysis showed six differentially expressed genes inside the PPVres locus. Two of them (ParPMC1 and ParPMC2), which are two of the MATHd genes previously identified, presented allelic variations linked to resistance and showed strong downregulation in the resistant plants. Since the ParPMC2 gene presented a 5-bp deletion that causes a premature stop codon, authors hypothesized that downregulation might be related to the induction of nonsense-mediated RNA decay and, concomitantly, of RNA silencing. In turn, RNA silencing could affect the intact allele as well as the homologous ParPMC1 transcripts, explaining the dominant effect of this mutation in Prunus spp. It is tempting to speculate that epigenetic changes in addition to the deletion in ParPMC2 contribute to the silencing of the MATHd genes, which would explain the genotype-phenotype discrepancies found in the marker-assisted selection of resistance based on the PPVres locus (Decroocq et al. 2014; Rubio et al. 2014).

Another kind of natural resistance that is worth mentioning is that of the almond (Prunus dulcis) cultivar Garrigues, which can be used as a source of "vaccination" by grafting onto susceptible 'GF305' peaches (Rubio et al. 2013). It was suggested that a specific factor is transferred through the graft junction from Garrigues to the peach tree to confer the resistance. This factor is still unknown, but it is possible that, similar to the observed effect in resistant apricots, it is causing epigenetic changes influencing one or both gene regulation and expression as well as PPV restriction. Further investigation is needed to understand the exact molecular mechanism that underlies this conferred resistance.

Model plants like Arabidopsis thaliana are not naturally infected by PPV. Nonetheless, experimental inoculations have shown that some varieties are susceptible to the virus while others are resistant. An early work with 12 different Arabidopsis accessions made clear that there was a wide source of genetic background that might confer resistance to different PPV isolates based on various mechanisms (Decroocq et al. 2006). For example, in that report, most accessions tested were resistant to PPV-C. The authors suggested the induction of two layers of resistance, a presumed $R$ gene-mediated response at the local level, and a second uncharacterized response restricting long-distance movement. A later work added complexity to this picture by linking the resistance of $A$. thaliana and Chenopodium foetidum to PPV-C to a deficient compatibility in the interaction between VPg and eIF4E/eIF(iso) 4E (Calvo et al. 2014a). This kind of passive response could be considered a lack of susceptibility more than an actual resistance.

Another Arabidopsis accession, Cvi-1, showed isolatespecific restriction of long-distance movement linked to the rpv1 locus. GWAS of 147 Arabidopsis accessions and fine mapping identified chloroplast phosphoglycerate kinase $(c P G K 2)$ as the gene that underlies this resistance (Poque et al. 2015). RTM genes of A. thaliana were identified as partners of a multicomponent resistance system that restricts the systemic movement of potyviruses in a dominant fashion (Cosson et al. 2012). This system is active against some PPV isolates, and viral determinants involved in RTM-mediated resistance were located in the N-terminal part of CP (Decroocq et al. 2009). The aforementioned host-range determinant involved in alternative adaptation to Nicotiana and Prunus species is also located in that particular region of the $\mathrm{CP}$ and it has been hypothesized to be related with a still unidentified RTM-like resistance system of Nicotiana plants (Carbonell et al. 2013). GWAS in A. thaliana also identified a recessive resistant locus termed sha3 (Pagny et al. 2012), which comprises RTM3, a MATHd gene, and several other RTM3-like genes, similar to the MATHd genes localized in the PPVres locus of PPV-resistant apricots. The recessive nature of the sha3 locus-mediated resistance contrasts with the dominant nature of RTM3 and PPVres, highlighting the complexity of the involvement of MATHd factors in anti-PPV resistance.

As mentioned above, $O$-GlcNAcylation and phosphorylation are cross-talking PTMs of CP relevant for PPV infection (Martínez-Turiño et al. 2018; Pérez et al. 2013). In $A$. thaliana, the $O$-GlcNAcyl transferase SECRET AGENT (SEC) was found to be responsible for PPV CP O-GlcNAcylation (Chen et al. 2005). Interestingly, mapping of QTL involved in PPV resistance, other than PPVres, in apricots detected a gene homologous to the Arabidopsis SEC, which suggests that the disturbance of $\mathrm{CP} O$-GlcNAcylation could be a possible contributor to the resistance against PPV (Lambert et al. 2007).

Other proteins have been involved in anti-PPV resistance in herbaceous hosts, such as in the case of the psaK gene, which encodes PSI-K, a chloroplastic protein that forms part of the photosystem I. Downregulation of its expression enhances PPV infection in $N$. benthamiana and A. thaliana, and the direct interaction of PSI-K with PPV CI promotes the degradation of the plant protein (Jiménez et al. 2006). Another example is the C-8 sterol isomerase HYDRA1 (HYD1), an enzyme involved in isoprenoid biosynthesis, whose overexpression has been recently demonstrated to interfere with PPV infection (Ochoa et al. 2019). As suggested, HYD1 might alter the particular 
composition and structure of cellular membranes involved in either antiviral RNA silencing, viral RNA replication, or both.

Advances in the knowledge of plant biology, viral life cycle, and the mechanisms underlying resistance allowed tackling alternative strategies to fight sharka disease, such as the generation of genetically modified plants resistant to PPV (Ilardi and Nicola-Negri 2011; Ilardi and Tavazza 2015) (Fig. 4B). Most of the engineered resistances in Prunus spp., the natural PPV hosts, have been based on PPV-derived sequences that enhance RNA silencing in the plant. The full-length CP cistron was used first (Ravelonandro et al. 1997), followed by intron-hairpin RNA from different genome regions (GarcíaAlmodóvar et al. 2015; Hily et al. 2007; Ravelonandro et al. 2014; Sidorova et al. 2018, 2019). The development of artificial miRNA or artificial transacting siRNA technologies provides new tools to take profit of RNA silencing in order to engineer antiviral resistance (Carbonell 2019). This novel approach has been tested against PPV in a herbaceous experimental system (Zhao et al. 2015). The greatest success in the generation of a genetically engineered PPV-resistant tree was the $P$. domestica cultivar Honey Sweet, registered by the Environmental Protection Agency in 2011 (Scorza et al. 2013). This transgenic plum was originated by transformation with the full-length sequence of the PPV CP gene and has been tested in the field for more than 20 years, showing resistance against all major PPV strains, even in mixed infections with other pathogens (Callahan et al. 2019; Polák et al. 2018; Ravelonandro et al. 1997; Scorza et al. 2016).

Plant genes have also been used as source of resistance via genetic modification. Translation factors eIF4E/eIF(iso)4E perform redundant functions in plants, but potyviruses usually are committed to use one specific allele from one of them. Taking advantage of this, silencing by hairpin RNA of the eiF(iso) $4 E$ gene in $P$. domestica deprived PPV of a necessary factor for viral infection, rendering transformed plants resistant to the virus (Wang et al. 2013). Nicotiana plants were successfully protected against the potyviruses TEV and potato virus $\mathrm{Y}$ by transformation with the gene encoding oryzacystatin I, a cysteine protease inhibitor of rice that would target potyviral NIapro (Gutierrez-Campos et al. 1999). However, studies on PPV with similar protease inhibitors did not show positive results, raising questions about this approach for an extended range of potyviruses, including PPV (García et al. 1993; Wen et al. 2004). NIapro was also the target of a novel antiviral approach that exploits its very specific protease activity to cleave an engineered sensor that guards an already characterized resistance gene (Kim et al. 2016). TEV and TuMV NIapro cleavage sites were tested, and, although this "decoy" strategy was only moderately successful and needs further adjustments, it represents a good opportunity to explore other ways of generating PPV-resistant plants.

Immunomodulation is another approach used to confer viral resistance in genetically modified plants. In this case, sequences introduced are neither viral nor related to a plant gene, but rather, single-chain antibodies specifically generated against one of the viral proteins. In a particular report, antibodies recognizing the NIb RNA replicase of PPV were constitutively expressed in $N$. benthamiana. Resistance displayed by the modified plants, although weak, opened new possibilities for the control of PPV and other potyviruses (Gil et al. 2011).

\section{CONCLUDING REMARKS}

Since its discovery in Bulgaria at the beginning of the 20th century, PPV has become one of the most relevant plantinfecting RNA viruses. Reasons for this status are described throughout this manuscript and can be summarized in the following two points: i) the enormous socioeconomic impact that sharka disease has and ii) the insight that scientists have gained and will keep on gaining thanks to the study of this virus. Regarding this second point, it is worth mentioning diverse pioneer discoveries made by using PPV as a model, which reveal the existence, uncover the role, or describe important features of the potyvirus biology, namely, the identification of $6 \mathrm{~K} 1$ as a proper viral cistron, the discovery of helicase/NTPase activities in CI, or the production of overlapping reading frames by an RNA polymerase slippage mechanism. Other interesting features of PPV might be species-specific or their generalization to other viral species has not yet been demonstrated, such as in the case of the $O$-GlcNAcylation of $\mathrm{CP}$, the role of HCpro in the formation or stability of viral particles, and the link between viral RNA replication and encapsidation, among other examples. Indeed, the lack of generalization of diverse findings encourages the use of systematic approaches aiming to determine to what extent an observation in a particular potyvirus or potyvirid applies to all members of the genus or family.

Numerous published studies on PPV helped identify specific viral determinants defining host range in herbaceous plants; however, data regarding viral factors modulating host-range definition in trees are still very scarce. Besides, it is remarkable that the molecular mechanism underpinning the most relevant outcomes of any plant-pathogen interaction, symptomatic disease and resistance, is still unknown in the PPV-Prunus pathosystem. Consequently, the comprehensive understanding of how PPV adapts to a new host, negatively affects the yield and quality of fruits, and how certain trees restrict PPV infection are, indeed, exciting topics for future investigations. It is envisaged that the filling of these gaps in our knowledge will provide new opportunities to develop innovative approaches to fight sharka disease and its negative impact in agriculture and food security.

\section{ACKNOWLEDGMENTS}

We apologize to those researchers whose relevant publications were not cited because of unintentional oversight.

\section{AUTHOR-RECOMMENDED INTERNET RESOURCE}

ICTV website: https://talk.ictvonline.org

\section{LITERATURE CITED}

Ala-Poikela, M., Goytia, E., Haikonen, T., Rajamäki, M.-L., and Valkonen, J. P. T. 2011. Helper component proteinase of the genus Potyvirus is an interaction partner of translation initiation factors eIF(iso)4E and eIF4E and contains a 4E binding motif. J. Virol. 85:6784-6794.

Ambros, V., Pettersson, R. F., and Baltimore, D. 1978. An enzymatic activity in uninfected cells that cleaves the linkage between poliovirion RNA and the 5' terminal protein. Cell 15:1439-1446.

Barba, M., Hadidi, A., Candresse, T., and Cambra, M. 2011. Plum pox virus. Pages 185-197 in: Virus and Virus-Like Disease of Pome and Stone Fruits. A. Hadidi, M. Barba, T. Cabdresse, and W. Jelkmann, eds. APS Press, St. Paul, MN, U.S.A.

Blanc, S., López-Moya, J. J., Wang, R., García-Lampasona, S., Thornbury, D. W., and Pirone, T. P. 1997. A specific interaction between coat protein and helper component correlates with aphid transmission of a potyvirus. Virology 231:141-147.

Callahan, A. M., Dardick, C. D., and Scorza, R. 2019. Multilocation comparison of fruit composition for 'HoneySweet', an RNAi based plum pox virus resistant plum. PLoS One 14:e0213993.

Calvo, M., Malinowski, T., and García, J. A. 2014b. Single amino acid changes in the 6K1-CI region can promote the alternative adaptation of Prunus- and Nicotiana-propagated Plum pox virus $\mathrm{C}$ isolates to either host. Mol. Plant-Microbe Interact. 27:136-149.

Calvo, M., Martínez-Turiño, S., and García, J. A. 2014a. Resistance to Plum pox virus strain $\mathrm{C}$ in Arabidopsis thaliana and Chenopodium foetidum 
involves genome-linked viral protein and other viral determinants and might depend on compatibility with host translation initiation factors. Mol. Plant-Microbe Interact. 27:1291-1301.

Cambra, M., and Vidal, E. 2017. Sharka, a vector-borne disease caused by Plum pox virus: Vector species, transmission mechanism, epidemiology and mitigation strategies to reduce its natural spread. Acta Hortic. 1163: 57-68.

Carbonell, A. 2019. Secondary small interfering RNA-based silencing tools in plants: An update. Front. Plant Sci. 10:687.

Carbonell, A., Dujovny, G., García, J. A., and Valli, A. 2012. The Cucumber vein yellowing virus silencing suppressor $\mathrm{P} 1 \mathrm{~b}$ can functionally replace HCPro in Plum pox virus infection in a host-specific manner. Mol. PlantMicrobe Interact. 25:151-164.

Carbonell, A., Maliogka, V. I., Pérez, Jde. J., Salvador, B., León, D. S., García, J. A., and Simón-Mateo, C. 2013. Diverse amino acid changes at specific positions in the N-terminal region of the coat protein allow Plum pox virus to adapt to new hosts. Mol. Plant-Microbe Interact. 26: 1211-1224.

Carrasco, J. L., Castelló, M. J., Naumann, K., Lassowskat, I., NavarreteGómez, M., Scheel, D., and Vera, P. 2014. Arabidopsis protein phosphatase DBP1 nucleates a protein network with a role in regulating plant defense. PLoS One 9:e90734.

Castelló, M. J., Carrasco, J. L., Navarrete-Gómez, M., Daniel, J., Granot, D., and Vera, P. 2011. A plant small polypeptide is a novel component of DNA-binding protein phosphatase 1-mediated resistance to Plum pox virus in Arabidopsis. Plant Physiol. 157:2206-2215.

Castelló, M. J., Carrasco, J. L., and Vera, P. 2010. DNA-binding protein phosphatase AtDBP1 mediates susceptibility to two potyviruses in Arabidopsis. Plant Physiol. 153:1521-1525.

Chapman, E. J., Prokhnevsky, A. I., Gopinath, K., Dolja, V. V., and Carrington, J. C. 2004. Viral RNA silencing suppressors inhibit the microRNA pathway at an intermediate step. Genes Dev. 18:1179-1186.

Chen, D., Juárez, S., Hartweck, L., Alamillo, J. M., Simón-Mateo, C., Pérez, J. J., Fernández-Fernández, M. R., Olszewski, N. E., and García, J. A. 2005. Identification of secret agent as the $O$-GlcNAc transferase that participates in plum pox virus infection. J. Virol. 79:9381-9387.

Chirkov, S., Ivanov, P., Sheveleva, A., Kudryavtseva, A., and Mitrofanova, I. 2018b. Molecular characterization of Plum pox virus Rec isolates from Russia suggests a new insight into evolution of the strain. Virus Genes 54:328-332.

Chirkov, S., Sheveleva, A., Ivanov, P., and Zakubanskiy, A. 2018a. Analysis of genetic diversity of russian sour cherry Plum pox virus isolates provides evidence of a new strain. Plant Dis. 102:569-575.

Cirilli, M., Geuna, F., Babini, A. R., Bozhkova, V., Catalano, L., Cavagna, B., Dallot, S., Decroocq, V., Dondini, L., Foschi, S., Ilardi, V., Liverani, A., Mezzetti, B., Minafra, A., Pancaldi, M., Pandolfini, T., Pascal, T., Savino, V. N., Scorza, R., Verde, I., and Bassi, D. 2016. Fighting sharka in peach: Current limitations and future perspectives. Front. Plant Sci. 7: 1290.

Clemente-Moreno, M. J., Díaz-Vivancos, P., Rubio, M., Fernández-García, N., and Hernández, J. A. 2013. Chloroplast protection in plum pox virusinfected peach plants by L-2-oxo-4-thiazolidine-carboxylic acid treatments: Effect in the proteome. Plant Cell Environ. 36:640-654.

Clemente-Moreno, M. J., Hernández, J. A., and Diaz-Vivancos, P. 2015. Sharka: How do plants respond to Plum pox virus infection? J. Exp. Bot. 66:25-35.

Collum, T. D., Stone, A. L., Sherman, D. J., Rogers, E. E., Dardick, C., and Culver, J. N. 2020. Translatome profiling of plum pox virus-infected leaves in European plum reveals temporal and spatial coordination of defense responses in phloem tissues. Mol. Plant-Microbe Interact. 33: 66-77.

Cosson, P., Schurdi-Levraud, V., Le, Q. H., Sicard, O., Caballero, M., Roux, F., Le Gall, O., Candresse, T., and Revers, F. 2012. The RTM resistance to potyviruses in Arabidopsis thaliana: Natural variation of the RTM genes and evidence for the implication of additional genes. PLoS One 7: e39169.

Cui, H., and Wang, A. 2016. Plum pox virus 6K1 protein Is required for viral replication and targets the viral replication complex at the early stage of infection. J. Virol. 90:5119-5131.

Cui, H., and Wang, A. 2019. The biological impact of the hypervariable N-terminal region of potyviral genomes. Annu. Rev. Virol. Published online.

Dallot, S., Quiot-Douine, L., Sáenz, P., Cervera, M. T., García, J. A., and Quiot, J. B. 2001. Identification of Plum pox virus determinants implicated in specific interactions with different Prunus spp. Phytopathology 91:159-164.

Decroocq, S., Chague, A., Lambert, P., Roch, G., Audergon, J. M., Geuna, F., Chiozzotto, R., Bassi, D., Dondini, L., Tartarini, S., Salava, J., Krška,
B., Palmisano, F., Karayiannis, I., and Decroocq, V. 2014. Selecting with markers linked to the PPVres major QTL is not sufficient to predict resistance to Plum Pox Virus (PPV) in apricot. Tree Genet. Genomes 10: 1161-1170.

Decroocq, V., Salvador, B., Sicard, O., Glasa, M., Cosson, P., SvanellaDumas, L., Revers, F., García, J. A., and Candresse, T. 2009. The determinant of potyvirus ability to overcome the RTM resistance of Arabidopsis thaliana maps to the $\mathrm{N}$-terminal region of the coat protein. Mol. Plant-Microbe Interact. 22:1302-1311.

Decroocq, V., Sicard, O., Alamillo, J. M., Lansac, M., Eyquard, J. P., García, J. A., Candresse, T., Le Gall, O., and Revers, F. 2006. Multiple resistance traits control Plum pox virus infection in Arabidopsis thaliana. Mol. Plant-Microbe Interact. 19:541-549.

Dehkordi, A. N., Rubio, M., Babaeian, N., Albacete, A., and MartínezGómez, P. 2018. Phytohormone signaling of the resistance to Plum pox virus (PPV, sharka disease) induced by almond (Prunus dulcis (Miller) Webb) grafting to peach (P. persica L. Batsch). Viruses 10: 238.

Diaz-Vivancos, P., Bernal-Vicente, A., Cantabella, D., Petri, C., and Hernández, J. A. 2017. Metabolomics and biochemical approaches link salicylic acid biosynthesis to cyanogenesis in peach plants. Plant Cell Physiol. 58:2057-2066.

Díaz-Vivancos, P., Clemente-Moreno, M. J., Rubio, M., Olmos, E., García, J. A., Martínez-Gómez, P., and Hernández, J. A. 2008. Alteration in the chloroplastic metabolism leads to ROS accumulation in pea plants in response to plum pox virus. J. Exp. Bot. 59:2147-2160.

Diaz-Vivancos, P., Rubio, M., Mesonero, V., Periago, P. M., Barceló, A. R., Martínez-Gómez, P., and Hernández, J. A. 2006. The apoplastic antioxidant system in Prunus: Response to long-term plum pox virus infection. J. Exp. Bot. 57:3813-3824.

Dolja, V. V., Haldeman, R., Robertson, N. L., Dougherty, W. G., and Carrington, J. C. 1994. Distinct functions of capsid protein in assembly and movement of tobacco etch potyvirus in plants. EMBO J. 13: 1482-1491.

Fernández, A., Guo, H. S., Sáenz, P., Simón-Buela, L., Gómez de Cedrón, M., and García, J. A. 1997. The motif V of plum pox potyvirus CI RNA helicase is involved in NTP hydrolysis and is essential for virus RNA replication. Nucleic Acids Res. 25:4474-4480.

Fernández-Fernández, M. R., Camafeita, E., Bonay, P., Méndez, E., Albar, J. P., and García, J. A. 2002. The capsid protein of a plant single-stranded RNA virus is modified by $O$-linked $N$-acetylglucosamine. J. Biol. Chem. 277:135-140.

Gabrenaite-Verkhovskaya, R., Andreev, I. A., Kalinina, N. O., Torrance, L., Taliansky, M. E., and Mäkinen, K. 2008. Cylindrical inclusion protein of potato virus $\mathrm{A}$ is associated with a subpopulation of particles isolated from infected plants. J. Gen. Virol. 89:829-838.

Gallo, A., Valli, A., Calvo, M., and García, J. A. 2018. A functional link between RNA replication and virion assembly in the potyvirus Plum pox virus. J. Virol. 92:e02179-17.

García, J. A., Cervera, M. T., Riechmann, J. L., and López-Otín, C. 1993. Inhibitory effects of human cystatin $\mathrm{C}$ on plum pox potyvirus proteases. Plant Mol. Biol. 22:697-701.

García, J. A., Glasa, M., Cambra, M., and Candresse, T. 2014. Plum pox virus and sharka: A model potyvirus and a major disease. Mol. Plant Pathol. 15:226-241.

García-Almodóvar, R. C., Clemente-Moreno, M. J., Díaz-Vivancos, P., Petri, C., Rubio, M., Padilla, I. M. G., Ilardi, V., and Burgos, L. 2015. Greenhouse evaluation confirms in vitro sharka resistance of genetically engineered h-UTR/P1 plum plants. Plant Cell Tiss. Org. 120:791-796.

Garcia Cabanillas, D., Jiang, J., Movahed, N., Germain, H., Yamaji, Y., Zheng, H., and Laliberté, J.-F. 2018. Turnip mosaic virus uses the SNARE protein VTI11 in an unconventional route for replication vesicle trafficking. Plant Cell 30:2594-2615.

Garcia-Ruiz, H. 2019. Host factors against plant viruses. Mol. Plant Pathol. Published online. https://doi.org/10.1111/mpp.12851

Gil, M., Esteban, O., García, J. A., Peña, L., and Cambra, M. 2011. Resistance to Plum pox virus in plants expressing cytosolic and nuclear single-chain antibodies against the viral RNA NIb replicase. Plant Pathol. 60:967-976.

Gómez de Cedrón, M., Osaba, L., López, L., and García, J. A. 2006. Genetic analysis of the function of the plum pox virus CI RNA helicase in virus movement. Virus Res. 116:136-145.

González-Jara, P., Atencio, F. A., Martínez-García, B., Barajas, D., Tenllado, F., and Díaz-Ruíz, J. R. 2005. A single amino acid mutation in the plum pox virus helper component-proteinase gene abolishes both synergistic and RNA silencing suppression activities. Phytopathology 95:894-901. 
Grangeon, R., Agbeci, M., Chen, J., Grondin, G., Zheng, H., and Laliberté, J. F. 2012. Impact on the endoplasmic reticulum and Golgi apparatus of turnip mosaic virus infection. J. Virol. 86:9255-9265.

Gutierrez-Campos, R., Torres-Acosta, J. A., Saucedo-Arias, L. J., and Gomez-Lim, M. A. 1999. The use of cysteine proteinase inhibitors to engineer resistance against potyviruses in transgenic tobacco plants. Nat. Biotechnol. 17:1223-1226.

Hajizadeh, M., Gibbs, A. J., Amirnia, F., and Glasa, M. 2019. The global phylogeny of Plum pox virus is emerging. J. Gen. Virol. Published online.

Harris, C. J., Slootweg, E. J., Goverse, A., and Baulcombe, D. C. 2013. Stepwise artificial evolution of a plant disease resistance gene. Proc. Natl. Acad. Sci. U.S.A. 110:21189-21194.

Hernández, J. A., Cano, J., Portillo, B., Rubio, M., and Martínez-Gómez, P. 2006. Antioxidant enzymes as biochemical markers for sharka resistance in apricot. Biol. Plant. 50:400-404.

Hily, J. M., Ravelonandro, M., Damsteegt, V., Bassett, C., Petri, C., Liu, Z., and Scorza, R. 2007. Plum pox virus coat protein gene Intron-hairpinRNA (ihpRNA) constructs provide resistance to plum pox virus in Nicotiana benthamiana and Prunus domestica. J. Am. Soc. Hortic. Sci. 132:850-858.

Huang, T. S., Wei, T., Laliberté, J. F., and Wang, A. 2010. A host RNA helicase-like protein, AtRH8, interacts with the potyviral genome-linked protein, VPg, associates with the virus accumulation complex, and is essential for infection. Plant Physiol. 152:255-266.

Hurtado, A., Romero, C., Vilanova, S., Abbott, G., Llácer, G., and Badenes, L. 2002. Genetic linkage maps of two apricot cultivars (Prunus armeniaca L.), and mapping of PPV (sharka) resistance. Theor. Appl. Genet. 105:182-191.

Ilardi, V., and Nicola-Negri, E. D. 2011. Genetically engineered resistance to Plum pox virus infection in herbaceous and stone fruit hosts. GM Crops 2:24-33.

Ilardi, V., and Tavazza, M. 2015. Biotechnological strategies and tools for Plum pox virus resistance: Trans-, intra-, cis-genesis, and beyond. Front. Plant Sci. 6:379.

Jakubiec, A., and Jupin, I. 2007. Regulation of positive-strand RNA virus replication: The emerging role of phosphorylation. Virus Res. 129: 73-79.

James, D., Sanderson, D., Varga, A., Sheveleva, A., and Chirkov, S. 2016. Genome sequence analysis of new isolates of the Winona strain of Plum pox virus and the first definitive evidence of intrastrain recombination events. Phytopathology 106:407-416.

James, D., Varga, A., and Sanderson, D. 2013. Genetic diversity of Plum pox virus: Strains, disease and related challenges for control. Can. J. Plant Pathol. 35:431-441.

Jiang, J., Patarroyo, C., Garcia Cabanillas, D., Zheng, H., and Laliberté, J. F. 2015. The vesicle-forming $6 \mathrm{~K} 2$ protein of turnip mosaic virus interacts with the COPII coatomer Sec24a for viral systemic infection. J. Virol. 89:6695-6710.

Jiménez, I., López, L., Alamillo, J. M., Valli, A., and García, J. A. 2006. Identification of a plum pox virus $\mathrm{CI}$-interacting protein from chloroplast that has a negative effect in virus infection. Mol. Plant-Microbe Interact. 19:350-358.

Kamenova, I., Tasheva-Terzieva, E., Dragoyski, K., and Stefanova, B. 2017. Spread and competitiveness of Plum Pox Virus: Rec and -D strains in experimental plum orchard. J. Phytopathol. 165:602-609.

Kerlan, C., and Dunez, J. 1979. Différenciation biologique et sérologique de souches du virus de la sharka. Ann. Phytopathol. 11:241-250.

Kim, S. H., Qi, D., Ashfield, T., Helm, M., and Innes, R. W. 2016. Using decoys to expand the recognition specificity of a plant disease resistance protein. Science 351:684-687.

Lambert, P., Dicenta, F., Rubio, M., and Audergon, J. M. 2007. QTL analysis of resistance to sharka disease in the apricot (Prunus armeniaca L.) 'Polonais' $\times$ 'Stark Early Orange' F1 progeny. Tree Genet. Genomes 3:299-309.

Lõhmus, A., Hafrén, A., and Mäkinen, K. 2017. Coat protein regulation by CK2, CPIP, HSP70 and CHIP is required for potato virus A replication and coat protein accumulation. J. Virol. 91:e01316.

Lõhmus, A., Varjosalo, M., and Mäkinen, K. 2016. Protein composition of 6K2-induced membrane structures formed during Potato virus A infection. Mol. Plant Pathol. 17:943-958.

Maliogka, V. I., Calvo, M., Carbonell, A., García, J. A., and Valli, A. 2012a. Heterologous RNA-silencing suppressors from both plant- and animalinfecting viruses support plum pox virus infection. J. Gen. Virol. 93: 1601-1611.

Maliogka, V. I., Salvador, B., Carbonell, A., Sáenz, P., León, D. S., Oliveros, J. C., Delgadillo, M. O., García, J. A., and Simón-Mateo, C. 2012 b. Virus variants with differences in the P1 protein coexist in a Plum pox virus population and display particular host-dependent pathogenicity features. Mol. Plant Pathol. 13:877-886.

Mann, K. S., and Sanfaçon, H. 2019. Expanding repertoire of plant positivestrand RNA virus proteases. Viruses 11:66.

Manoussopoulos, I. N., Maiss, E., and Tsagris, M. 2000. Native electrophoresis and Western blot analysis (NEWeB): A method for characterization of different forms of potyvirus particles and similar nucleoprotein complexes in extracts of infected plant tissues. J. Gen. Virol. 81:2295-2298.

Mariette, S., Wong Jun Tai, F., Roch, G., Barre, A., Chague, A., Decroocq, S., Groppi, A., Laizet, Y., Lambert, P., Tricon, D., Nikolski, M., Audergon, J. M., Abbott, A. G., and Decroocq, V. 2016. Genome-wide association links candidate genes to resistance to Plum Pox Virus in apricot (Prunus armeniaca). New Phytol. 209:773-784.

Martin, M. T., Cervera, M. T., Garcia, J. A., and Bonay, P. 1995. Properties of the active plum pox potyvirus RNA polymerase complex in defined glycerol gradient fractions. Virus Res. 37:127-137.

Martínez-Turiño, S., Pérez, J. J., Hervás, M., Navajas, R., Ciordia, S., Udeshi, N. D., Shabanowitz, J., Hunt, D. F., and García, J. A. 2018 Phosphorylation coexists with $O$-GlcNAcylation in a plant virus protein and influences viral infection. Mol. Plant Pathol. 19: 1427-1443.

Miras, M., Miller, W. A., Truniger, V., and Aranda, M. A. 2017. Noncanonical translation in plant RNA viruses. Front. Plant Sci. 8:494.

Movahed, N., Patarroyo, C., Sun, J., Vali, H., Laliberté, J. F., and Zheng, H. 2017. Cylindrical inclusion protein of turnip mosaic virus serves as a docking point for the intercellular movement of viral replication vesicles. Plant Physiol. 175:1732-1744.

Nagy, P. D., and Pogany, J. 2012. The dependence of viral RNA replication on co-opted host factors. Nat. Rev. Microbiol. 10:137-149.

Nagy, P. D., Wang, R. Y., Pogany, J., Hafren, A., and Makinen, K. 2011. Emerging picture of host chaperone and cyclophilin roles in RNA virus replication. Virology 411:374-382.

Neumüller, M., Hartmann, W., Petruschke, M., and Treutter, D. 2010. The hypersensitivity resistance of european plum to the Plum pox virus and its potential impact on the epidemiology of the virus. Julius-Kühn-Arch. 427:147-150

Nicaise, V., and Candresse, T. 2017. Plum pox virus capsid protein suppresses plant pathogen-associated molecular pattern (PAMP) triggered immunity. Mol. Plant Pathol. 18:878-886.

Nicaise, V., Gallois, J. L., Chafiai, F., Allen, L. M., Schurdi-Levraud, V., Browning, K. S., Candresse, T., Caranta, C., Le Gall, O., and GermanRetana, S. 2007. Coordinated and selective recruitment of eIF4E and eIF4G factors for potyvirus infection in Arabidopsis thaliana. FEBS Lett. 581:1041-1046.

Nováková, S., Danchenko, M., Skultety, L., Fialová, I., Lešková, A., Beke, G., Flores-Ramírez, G., and Glasa, M. 2018. Photosynthetic and stress responsive proteins are altered more effectively in Nicotiana benthamiana infected with Plum pox virus aggressive PPV-CR versus mild PPV-C cherry-adapted isolates. J. Proteome Res. 17:3114-3127.

Ochoa, J., Valli, A., Martín-Trillo, M., Simón-Mateo, C., García, J. A., and Rodamilans, B. 2019. Sterol isomerase HYDRA1 interacts with RNA silencing suppressor $\mathrm{P} 1 \mathrm{~b}$ and restricts potyviral infection. Plant Cell Environ. Published online.

Pagny, G., Paulstephenraj, P. S., Poque, S., Sicard, O., Cosson, P., Eyquard, J. P., Caballero, M., Chague, A., Gourdon, G., Negrel, L., Candresse, T., Mariette, S., and Decroocq, V. 2012. Family-based linkage and association mapping reveals novel genes affecting Plum pox virus infection in Arabidopsis thaliana. New Phytol. 196:873-886.

Pallas, V., and García, J. A. 2011. How do plant viruses induce disease? Interactions and interference with host components. J. Gen. Virol. 92: 2691-2705

Park, S. H., Li, F., Renaud, J., Shen, W., Li, Y., Guo, L., Cui, H., Sumarah, M., and Wang, A. 2017. NbEXPA1, an $\alpha$-expansin, is plasmodesmataspecific and a novel host factor for potyviral infection. Plant J. 92: 846-861.

Pasin, F., Simón-Mateo, C., and García, J. A. 2014. The hypervariable amino-terminus of $\mathrm{P} 1$ protease modulates potyviral replication and host defense responses. PLoS Pathog. 10:e1003985.

Pérez, Jde. J., Udeshi, N. D., Shabanowitz, J., Ciordia, S., Juárez, S., Scott, C. L., Olszewski, N. E., Hunt, D. F., and García, J. A. 2013. O-GlcNAc modification of the coat protein of the potyvirus Plum pox virus enhances viral infection. Virology 442:122-131.

Polák, J., Neubauerová, T., Komínek, P., and Kundu, J. K. 2018. Reaction of transgenic plum cv. HoneySweet to the Plum pox virus after a severe infection of Monilinia sp. Plant Prot. Sci. 55:8-10.

Poque, S., Pagny, G., Ouibrahim, L., Chague, A., Eyquard, J. P., Caballero, M., Candresse, T., Caranta, C., Mariette, S., and Decroocq, V. 2015. 
Allelic variation at the $r p v 1$ locus controls partial resistance to Plum pox virus infection in Arabidopsis thaliana. BMC Plant Biol. 15:159.

Ravelonandro, M., Scorza, R., Bachelier, J. C., Labonne, G., Levy, L., Damsteegt, V., Callahan, A. M., and Dunez, J. 1997. Resistance of transgenic Prunus domestica to plum pox virus infection. Plant Dis. 81: 1231-1235.

Ravelonandro, M., Scorza, R., Hily, J. M., and Briard, P. 2014. The efficiency of RNA interference for conferring stable resistance to plum pox virus. Plant Cell Tiss. Org. 118:347-356.

Riechmann, J. L., Cervera, M. T., and García, J. A. 1995. Processing of the plum pox virus polyprotein at the $\mathrm{P} 3-6 \mathrm{~K}_{1}$ junction is not required for virus viability. J. Gen. Virol. 76:951-956.

Riechmann, J. L., Laín, S., and García, J. A. 1991. Identification of the initiation codon of plum pox potyvirus genomic RNA. Virology 185: 544-552.

Rimbaud, L., Dallot, S., Gottwald, T., Decroocq, V., Jacquot, E., Soubeyrand, S., and Thébaud, G. 2015. Sharka epidemiology and worldwide management strategies: Learning lessons to optimize disease control in perennial plants. Annu. Rev. Phytopathol. 53:357-378.

Robaglia, C., and Caranta, C. 2006. Translation initiation factors: A weak link in plant RNA virus infection. Trends Plant Sci. 11:40-45.

Rodamilans, B., San León, D., Mühlberger, L., Candresse, T., Neumüller, M., Oliveros, J. C., and García, J. A. 2014. Transcriptomic analysis of Prunus domestica undergoing hypersensitive response to plum pox virus infection. PLoS One 9:e100477.

Rodamilans, B., Shan, H., Pasin, F., and García, J. A. 2018. Plant viral proteases: Beyond the role of peptide cutters. Front. Plant Sci. 9:666.

Rodamilans, B., Valli, A., Mingot, A., San León, D., Baulcombe, D. López-Moya, J. J., and García, J. A. 2015. RNA polymerase slippage as a mechanism for the production of frameshift gene products in plant viruses of the potyviridae family. J. Virol. 89:6965-6967.

Roossinck, M. J. 2012. Plant virus metagenomics: Biodiversity and ecology. Annu. Rev. Genet. 46:359-369.

Rubio, M., Ballester, A. R., Olivares, P. M., Castro de Moura, M., Dicenta, F., and Martínez-Gómez, P. 2015a. Gene expression analysis of Plum pox virus (sharka) susceptibility/resistance in apricot (Prunus armeniaca L.). PLoS One 10:e0144670.

Rubio, M., Martínez-Gómez, P., García, J. A., and Dicenta, F. 2013. Interspecific transfer of resistance to Plum pox virus from almond to peach by grafting. Ann. Appl. Biol. 163:466-474.

Rubio, M., Rodríguez-Moreno, L., Ballester, A. R., de Moura, M. C., Bonghi, C., Candresse, T., and Martínez-Gómez, P. 2015b. Analysis of gene expression changes in peach leaves in response to Plum pox virus infection using RNA-seq. Mol. Plant Pathol. 16:164-176.

Rubio, M., Ruiz, D., Egea, J., Martínez-Gómez, P., and Dicenta, F. 2014. Opportunities of marker-assisted selection for Plum pox virus resistance in apricot breeding programs. Tree Genet. Genomes 10:513-525.

Sáenz, P., Quiot, L., Quiot, J.-B., Candresse, T., and García, J. A. 2001. Pathogenicity determinants in the complex virus population of a Plum pox virus isolate. Mol. Plant-Microbe Interact. 14:278-287.

Sáenz, P., Salvador, B., Simón-Mateo, C., Kasschau, K. D., Carrington, J. C., and García, J. A. 2002. Host-specific involvement of the HC protein in the long-distance movement of potyviruses. J. Virol. 76: 1922-1931.

Salvador, B., Delgadillo, M. O., Sáenz, P., García, J. A., and Simón-Mateo, C. 2008a. Identification of Plum pox virus pathogenicity determinants in herbaceous and woody hosts. Mol. Plant-Microbe Interact. 21:20-29.

Salvador, B., Saénz, P., Yangüez, E., Quiot, J. B., Quiot, L., Delgadillo, M. O., García, J. A., and Simón-Mateo, C. 2008b. Host-specific effect of P1 exchange between two potyviruses. Mol. Plant Pathol. 9:147-155.

Schaad, M. C., Jensen, P. E., and Carrington, J. C. 1997. Formation of plant RNA virus replication complexes on membranes: Role of an endoplasmic reticulum-targeted viral protein. EMBO J. 16:4049-4059.

Scholthof, K.-B. G., Adkins, S., Czosnek, H., Palukaitis, P., Jacquot, E., Hohn, T., Hohn, B., Saunders, K., Candresse, T., Ahlquist, P., Hemenway, C., and Foster, G. D. 2011. Top 10 plant viruses in molecular plant pathology. Mol. Plant Pathol. 12:938-954.

Scorza, R., Callahan, A., Dardick, C., Ravelonandro, M., Polak, J., Malinowski, T., Zagrai, I., Cambra, M., and Kamenova, I. 2013. Genetic engineering of Plum pox virus resistance: 'HoneySweet' plum-From concept to product. Plant Cell Tiss. Org. 115:1-12.

Scorza, R., Ravelonandro, M., Callahan, A., Zagrai, I., Polak, J., Malinowski, T., Cambra, M., Levy, L., Damsteegt, V., Krška, B., Cordts, J., Gonsalves, D., and Dardick, C. 2016. 'HoneySweet' (C5), the first genetically engineered Plum pox virus-resistant plum (Prunus domestica L.) cultivar. HortScience 51:601-603.

Shan, H., Pasin, F., Tzanetakis, I. E., Simón-Mateo, C., García, J. A., and Rodamilans, B. 2018. Truncation of a P1 leader proteinase facilitates potyvirus replication in a non-permissive host. Mol. Plant Pathol. 19: 1504-1510.

Shan, H., Pasin, F., Valli, A., Castillo, C., Rajulu, C., Carbonell, A., SimónMateo, C., García, J. A., and Rodamilans, B. 2015. The Potyviridae P1a leader protease contributes to host range specificity. Virology 476 : 264-270.

Sidorova, T., Mikhailov, R., Pushin, A., Miroshnichenko, D., and Dolgov, S. 2019. Agrobacterium-mediated transformation of Russian commercial plum cv. "Startovaya" (Prunus domestica L.) with vius-derived hairpin RNA construct confers durable resistance to PPV infection in mature plants. Front. Plant Sci. 10:286.

Sidorova, T., Pushin, A., Miroshnichenko, D., and Dolgov, S. 2018. Generation of transgenic rootstock plum ((Prunus pumila L $\times$ P. salicina Lindl. $) \times(P$. cerasifera Ehrh. $))$ using hairpin-RNA construct for resistance to the Plum pox virus. Agronomy 8:2.

Sihelská, N., Glasa, M., and Šubr, Z. W. 2017. Host preference of the major strains of Plum pox virus-Opinions based on regional and world-wide sequence data. J. Integr. Agric. 16:510-515.

Simón-Buela, L., Guo, H. S., and García, J. A. 1997a. Cap-independent leaky scanning as the mechanism of translation initiation of a plant viral genomic RNA. J. Gen. Virol. 78:2691-2699.

Simón-Buela, L., Guo, H. S., and García, J. A. 1997b. Long sequences in the $5^{\prime}$ noncoding region of plum pox virus are not necessary for vira infectivity but contribute to viral competitiveness and pathogenesis. Virology 233:157-162.

Sochor, J., Babula, P., Adam, V., Krska, B., and Kizek, R. 2012. Sharka: The past, the present and the future. Viruses 4:2853-2901.

Šubr, Z., Kamencayová, M., and Glasa, M. 2015. Experimental mixed infection by Plum pox virus strains confirms their natural host preference. Acta Hortic. 1063:29-32.

Subr, Z., Ryšlavá, H., and Kollerová, E. 2007. Electrophoretic mobility of the capsid protein of the plum pox virus strain PPV-Rec indicates its partial phosphorylation. Acta Virol. 51:135-138.

Torrance, L., Andreev, I. A., Gabrenaite-Verhovskaya, R., Cowan, G., Mäkinen, K., and Taliansky, M. E. 2006. An unusual structure at one end of potato potyvirus particles. J. Mol. Biol. 357:1-8.

Truniger, V., and Aranda, M. A. 2009. Recessive resistance to plant viruses. Adv. Virus Res. 75:119-159, 231.

Uchiyama, A., Shimada-Beltran, H., Levy, A., Zheng, J. Y., Javia, P. A., and Lazarowitz, S. G. 2014. The Arabidopsis synaptotagmin SYTA regulates the cell-to-cell movement of diverse plant viruses. Front. Plant Sci. 5:584.

Valli, A., Gallo, A., Calvo, M., de Jesús Pérez, J., and García, J. A. 2014. A novel role of the potyviral helper component proteinase contributes to enhance the yield of viral particles. J. Virol. 88:9808-9818.

Valli, A., López-Moya, J. J., and García, J. A. 2007. Recombination and gene duplication in the evolutionary diversification of $\mathrm{P} 1$ proteins in the family Potyviridae. J. Gen. Virol. 88:1016-1028.

van der Horst, S., Snel, B., Hanson, J., and Smeekens, S. 2019. Novel pipeline identifies new upstream ORFs and non-AUG initiating main ORFs with conserved amino acid sequences in the 5' leader of mRNAs in Arabidopsis thaliana. RNA 25:292-304.

Verchot, J., and Carrington, J. C. 1995. Evidence that the potyvirus P1 proteinase functions in trans as an accessory factor for genome amplification. J. Virol. 69:3668-3674.

Vijayapalani, P., Maeshima, M., Nagasaki-Takekuchi, N., and Miller, W. A. 2012. Interaction of the trans-frame potyvirus protein P3N-PIPO with host protein PCaP1 facilitates potyvirus movement. PLoS Pathog. 8: e1002639.

Vozárová, Z., Kamencayová, M., Glasa, M., and Šubr, Z. 2013. Plum pox virus accumulates mutations in different genome parts during a longterm maintenance in Prunus host plants and passage in Nicotiana benthamiana. Acta Virol. 57:369-372.

Wallis, C. M., Stone, A. L., Sherman, D. J., Damsteegt, V. D., Gildow, F. E. and Schneider, W. L. 2007. Adaptation of plum pox virus to a herbaceous host (Pisum sativum) following serial passages. J. Gen. Virol. 88: 2839-2845.

Waltermann, A., and Maiss, E. 2006. Detection of 6K1 as a mature protein of $6 \mathrm{kDa}$ in plum pox virus-infected Nicotiana benthamiana. J. Gen. Virol. 87:2381-2386.

Wan, J., Cabanillas, D. G., Zheng, H., and Laliberté, J. F. 2015. Turnip mosaic virus moves systemically through both phloem and xylem as membrane-associated complexes. Plant Physiol. 167:1374-1388.

Wang, A. 2015. Dissecting the molecular network of virus-plant interactions: The complex roles of host factors. Annu. Rev. Phytopathol. 53:45-66

Wang, X., Kohalmi, S. E., Svircev, A., Wang, A., Sanfaçon, H., and Tian, L. 2013. Silencing of the host factor $e I F$ (iso) $4 E$ gene confers plum pox virus resistance in plum. PLoS One 8:e50627. 
Wei, T., and Wang, A. 2008. Biogenesis of cytoplasmic membranous vesicles for plant potyvirus replication occurs at endoplasmic reticulum exit sites in a COPI- and COPII-dependent manner. J. Virol. 82: 12252-12264.

Wei, T., Zhang, C., Hong, J., Xiong, R., Kasschau, K. D., Zhou, X., Carrington, J. C., and Wang, A. 2010. Formation of complexes at plasmodesmata for potyvirus intercellular movement is mediated by the viral protein P3N-PIPO. PLoS Pathog. 6:e1000962.

Wei, T., Zhang, C., Hou, X., Sanfaçon, H., and Wang, A. 2013. The SNARE protein Syp71 is essential for turnip mosaic virus infection by mediating fusion of virus-induced vesicles with chloroplasts. PLoS Pathog. 9: e1003378.

Wen, R., Zhang, S. C., Michaud, D., and Sanfaçon, H. 2004. Inhibitory effects of cystatins on proteolytic activities of the Plum pox potyvirus cysteine proteinases. Virus Res. 105:175-182.

Wu, X., Valli, A., García, J. A., Zhou, X., and Cheng, X. 2019. The tug-ofwar between plants and viruses: Great progress and many remaining questions. Viruses 11:203.
Zeenko, V., and Gallie, D. R. 2005. Cap-independent translation of tobacco etch virus is conferred by an RNA pseudoknot in the 5'-leader. J. Biol. Chem. 280:26813-26824.

Zhao, M., San León, D., Mesel, F., García, J. A., and Simón-Mateo, C. 2015. Assorted processing of synthetic trans-acting siRNAs and its activity in antiviral resistance. PLoS One 10:e0132281.

Zilian, E., and Maiss, E. 2011. Detection of plum pox potyviral proteinprotein interactions in planta using an optimized mRFP-based bimolecular fluorescence complementation system. J. Gen. Virol. 92: 2711-2723.

Zuriaga, E., Romero, C., Blanca, J. M., and Badenes, M. L. 2018. Resistance to Plum Pox Virus (PPV) in apricot (Prunus armeniaca L.) is associated with down-regulation of two MATHd genes. BMC Plant Biol. $18: 25$.

Zuriaga, E., Soriano, J. M., Zhebentyayeva, T., Romero, C., Dardick, C. Cañizares, J., and Badenes, M. L. 2013. Genomic analysis reveals MATH gene(s) as candidate(s) for Plum pox virus (PPV) resistance in apricot (Prunus armeniaca L.). Mol. Plant Pathol. 14:663-677. 